\title{
Occupational Hazards in Dentistry
}

\begin{abstract}
Abhirami*
Department of Dental Surgery, India

*Corresponding Author: Abhirami, Department of Dental Surgery, India.
\end{abstract}

DOI: 10.31080/ASDS.2020.04.0900
Received: June 27, 2020

Published: July 30, 2020

(C) All rights are reserved by Abhirami.

\begin{abstract}
Dental care has been revolutionized due to information explosion and technical advances, as a result of these advances quality care can be provided to the population but while doing so, dentist and their teams exposed to a number of hazards peculiar to this profession leading to various ailments specific to the profession that develop and intensify with years.
\end{abstract}

Keywords: Occupational Hazards; Dentistry

Occupational hazard can be defined as a risk to a person usually arising out of employment. It can also refer to a work, material, substance, process, or situation that predisposes or itself causes accidents or diseased a work place.

The history of occupational hazard awareness can be traced back to the $18^{\text {th }}$ century when "Bernadine ramazzini" who is referred to as the father of occupational medicine", recognized the role of occupation in the dynamics of health and diseases.

The practice of dentistry exposes dental professionals to a variety of work related hazards. These includes:

- Working in a sanitary state

- Working at a high level of concentration for long hours

- Working with anxious patients

- $\quad$ Exposure to microbial aerosols generated by high speed rotary hand pieces.

- Exposure to various chemicals used in clinical dental practice

- $\quad$ Other hazards.
Major occupational hazards

The major occupational hazards are:

- Biological health hazards

- Physical hazards

- Chemical hazards

- Musculoskeletal disorders and diseases of the PNS

- Mechanical hazards

- Psychosocial hazards

- $\quad$ Stress

- Legal hazards

- $\quad$ Other risks.

\section{Biological hazards}

The dental environment is associated with a significant risk of exposure to various microorganisms. Many infectious agents may be present in blood or saliva as a consequence of bacteremia or vermeil associated with systemic infections. Dental patients and dental health care workers may be exposed to a variety of microorganisms via blood or oral or respiratory secretion. It includes cytomegalovirus, hepatitis B virus (HBV), hepatitis c virus (HCV), her- 
pes simplex virus types 1 and 2, human immunodeficiency virus (HIV), mycobacterium tuberculosis, staphylococci, streptococci, and other viruses and bacteria especially those that infect the upper respiratory tract.

\section{Herpes virus infections}

Herpes viruses are characterized by their ability to established latent infection, with asymptomatic shedding of herpes virus in saliva.

\section{Acute viral hepatitis}

Viral hepatitis is currently divided into five primary types A, B, C, D, E.

\section{Hepatitis A}

Blood and secretions probably transmit hepatitis A but fecal shedding of the virus also occurs during the incubation period and ceases after symptoms begin. Most infections are subclinical. The incubation period is 2 - 6 weeks.

\section{Hepatitis C}

It is also called parent rally transmitted non-Anon-B hepatitis (PT-NANB). It can be transmitted by blood and a chronic carrier state exists in $20-50 \%$ of cases. The incubation period is $2-25$ weeks.

\section{Hepatitis D (Delta hepatitis)}

Hepatitis d virus is dependent on hepatitis B virus for replication. Therefore, immunization with hepatitis $B$ vaccine will prevent infection. HDV is a defective virus that requires the HBs Ag for its replication and growth.

\section{Hepatitis E}

It is the epidemic endemic form of non-A non-B hepatitis. It has a fecal-oral mode of transmission i.e. through ingestion of contaminated water or food containing hepatitis B virus.

\section{Hepatitis B}

The infective particle consists of an inner core plus an outer surface coat. The core contains DNA and DNA polymerase and replicates in the infected liver cells. The surface coat can be detected in serum by immunological reactions. The first humeral response to HBV infection is the development of IgM antibody to HBVAg (Anti Hob). It develops in all patients with HBV infection and persists indefinitely.
Anti-HBs is responsible for long term immunity. The hepatitis B early antigen correlates with HBV replication and high infectivity. Anti-HBe correlates with lower infectivity.

\section{Signs and symptoms of hepatitis B infection}

It varies from a mild flu like illness to fulminant, fatal liver failure depending on the individuals general health and immune response. The incubation period is 45 to 160 days, the average being 60 - 120 days. The onset of acute disease is generally insidious. The prodromal phase begins suddenly with anorexia, malaise, nausea, vomiting and fever. Urticaria and arthralgia may also occur. After 3 to 10 days, dark urine appears followed by jaundice. After 1 to 2 weeks jaundice fades and recovery begins in 2 to 4 weeks. sequel to this infection could be asymptomatic or symptomatic carrier state, cirrhosis, acute hepatitis infection, primary liver cancer or death.

\section{Modes of transmission in dentistry}

- $\quad$ HBV is transmitted both percutaneously and non-percutaneously.

- During treatment multiple opportunities exist for inadvertent percutaneous wounds to the operator and staff.

- Non percutaneous transmission in the dental environment includes transfer of infectious bodily secretions such as saliva, blood and crevicular fluid.

- Dental practitioners are considered as a group with one of the highest risk exposures to HBV.

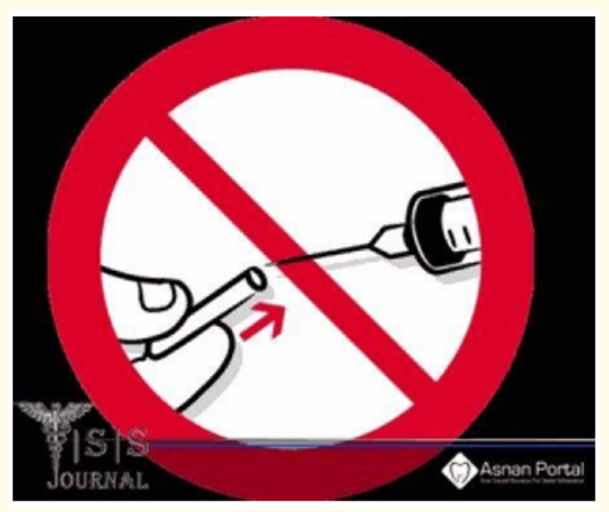

Figure 1 


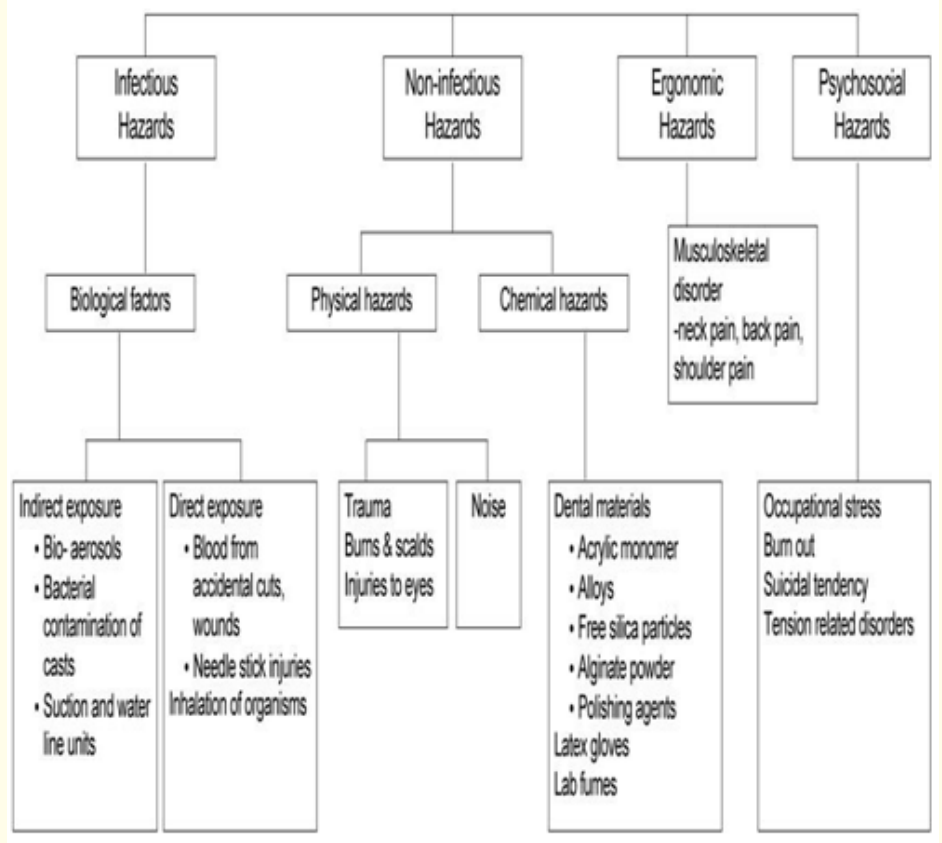

Figure 2: Types of infection

\section{Physical hazards}

The dentist and the clinical staff are at risk of physical injuries during many dental procedures. sources of physical injury can include debris from the oral cavity striking the eyes, cuts from sharp instruments, or puncture wounds from needles or other sharp instruments. Such injuries can result in the transmission of serious infectious disease to the dental worker. It comprises:

- Heat and cold: The common physical hazard in most industries in heat. The direct effect of heat exposure are burns, heat exhaustion, heat stroke and heat cramps, important hazards associated with cold work are chilblains, erythrocyanosis, immersion foot and frostbite as a result of cutaneous vasoconstriction.

- Light: The acute effects of poor illumination are eyestrain, headache, eye pain, lachrymation, congestion, around the cornea, and the chronic effects on health includes" miner's nystagmus". Exposure to excessive brightness is associated with discomfort, annoyance, and visual fatigue.

- $\quad$ Noise: Auditory effects which consist of temporary or permanent hearing loss. Non auditory effects which consists of nervousness, fatigue, interference with speech.

- Vibration: Vibration affects hands and arms. After some months or years of exposure, the fine blood vessels of the fingers may be increasingly sensitive to spasm.
- Ultraviolet radiation: Occupational exposure to ultraviolet radiation occurs mainly in arc welding. Such radiation affects the eye, causing intense conjunctivitis and keratitis.

- Ionizing radiation: Ionizing radiation are finding increased application in medicine and industry. $\mathrm{X}$ rays and radioactive isotopes are widely used. The radiation hazards comprises of genetic changes, malformation, cancer, leukemia, ulceration and sterility and in extreme cases the death.

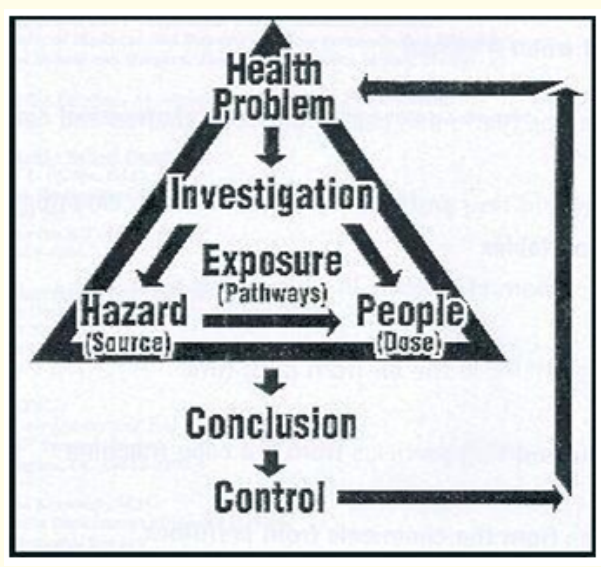

Figure 3 


\begin{tabular}{|c|c|c|}
\hline Structure Affected & Etiologic Agent & Manifestation \\
\hline $\begin{array}{l}\text { Tooth enamel and } \\
\text { dentin }\end{array}$ & $\begin{array}{c}\text { Dust } \\
\text { Pretension of instruments } \\
\text { Acids } \\
\text { Sugar }\end{array}$ & $\begin{array}{c}\text { Staining } \\
\text { Abrasion } \\
\text { Decalcification } \\
\text { Caries }\end{array}$ \\
\hline Gingiva & $\begin{array}{l}\text { Dust, mercury compounds } \\
\text { Dust, heavy metals } \\
\text { Variation in atmospheric pressure, benzene } \\
\text { acid, } \\
\text { mercurial compounds mercurial compounds } \\
\text { Dust flour }\end{array}$ & $\begin{array}{c}\text { Gingivitis } \\
\text { Pigmentation } \\
\text { Hemorrhage } \\
\text { Ulceration } \\
\text { Periodontitis } \\
\text { Calculus }\end{array}$ \\
\hline Periodontal membrane & $\begin{array}{c}\text { Mercurial compounds } \\
\text { Dust, flour }\end{array}$ & $\begin{array}{c}\text { Periodontitis } \\
\text { Calculus }\end{array}$ \\
\hline Alveolar bone and jaws & $\begin{array}{l}\text { As, } \mathrm{Cr}, \mathrm{Hg}, \mathrm{P}, \mathrm{Ra} \\
\text { Fluorine }\end{array}$ & $\begin{array}{c}\text { Osteomyelitis and necrosis } \\
\text { Sclerosis }\end{array}$ \\
\hline Lips & $\begin{array}{c}\text { Low humidity } \\
\text { Dust } \\
\text { Aniline carbon monoxide } \\
\text { Tar }\end{array}$ & $\begin{array}{c}\text { Dryness, fissure } \\
\text { Cheilitis, leukoplakia } \\
\text { Coloration of lips } \\
\text { Carcinoma }\end{array}$ \\
\hline Oral mucosa & Dust chemicals & Pigmentation stomatitis. \\
\hline Tongue & Food tasting & Anesthesia, parasthesia \\
\hline Salivary glands & $\begin{array}{c}\text { Mercury compounds } \\
\text { Xray radium } \\
\text { Increased intraoral pressure }\end{array}$ & $\begin{array}{c}\text { Ulceration, ptyalism } \\
\text { Xerostomia pneumatocele. }\end{array}$ \\
\hline
\end{tabular}

Table 1: Oral manifestations of occupational diseases.

\section{Chemical hazards}

The chemical environment is one of the most rapidly expanding components of the work environment because new chemicals and solutions are being introduced regularly.

Many biomaterials and auxiliary products used in dentistry are chemically reactive. Hazardous chemical agents used in clinical dentistry include mercury, powdered natural rubber latex (NRL), Disinfectants and nitrous oxide $\left(\mathrm{N}_{2} \mathrm{O}\right)$. By far the most important and most dangerous of these agents is mercury.

\section{Mercury}

Its use in dental amalgam has the potential for continuous occupational exposure of a dental practitioner to mercurial vapor which can be absorbed via the skin and lungs. The active component in the mercurial vapor has an affinity for brain tissue.

Mercury poisoning can be characterized by tumors of the face, arms or legs and can also be associated with progressive, tremulous illegible handwriting and slurred speech. It is advisable to conduct regular mercury vapor assessments in clinical settings; receive episodic individual amalgam blood level tests; and use goggles, water spray, and suction during the removal of old amalgam restorations.

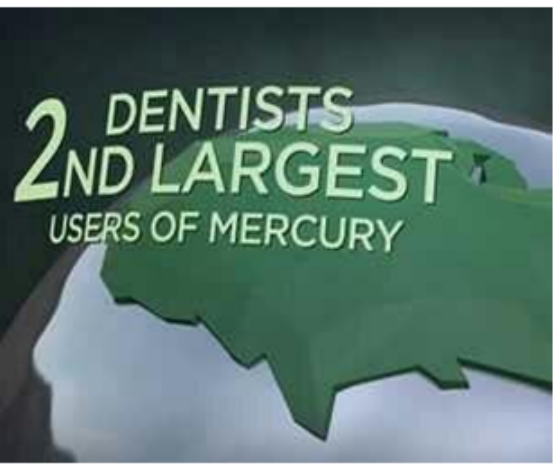

Figure 4 


\section{Latex hypersensitivity}

Gloves and mask form an integral part of dentist's protective equipment. Latex gloves dusted with com starch powder are most often used. The gloves and the mask form an efficient barrier against most pathogens; they also constitute a very good barrier against viruses, provided they are intact.

However, they may also be a source of allergies, primarily in those persons who use rubber products on a regular basis.

Chemical hazards act in three ways:

- Local action

- Inhalation and

- Ingestion.

\section{Local action}

Some chemicals are absorbed through the skin and cause systemic effects. Occupational dermatitis are due to machine oil, rubber, x-rays, caustic alkalis and lime.

\section{Inhalation}

- Gases: Carbon di- oxide, carbon monoxide, cyanide gas, sulphur dioxide etc. causes gas poisoning.

- Dusts: Inorganic dusts such as coal dust, silica, asbestos, iron causes anthracosis, silicosis, asbestosis, cancer lung, siderosis. Organic dust such as cane fibre, cotton dust, tobacco, hay or grain dust Causes bagassosis, byssinosis, tobaccosis, and farmer's lung.

- Metals and their compounds: Toxic hazards occur from lead, mercury, cadmium, manganese, arsenic, chromium etc.

\section{Ingestion}

Occupational diseases may also result from ingestion of chemical substances such as lead, mercury, arsenic, zinc, cadmium, phosphorous, etc.

\section{Musculoskeletal disorders and diseases of PNS}

At work, the dentist assumes a strained posture both while standing and sitting close to a patient, while providing care which causes an overstress of the spine and limbs and the peripheral nervous system (PNS).
This results in back pain syndrome, neck discopathy, cervicocranial pains and carpel tunnel syndrome.

\section{Carpel tunnel syndrome}

It is a defect of the median nerve and cubital nerve. In its early phase, it is manifested as paresthesia of thumb and index finger which is accompanied by disorders of the thumb and index finger as well as by the atrophy of the thenar.

Carpel tunnel syndrome is also seen in dental professionals due to the Vibrations of hand instruments.

\section{Mechanical hazards}

The mechanical hazards in industry centre around machinery, protruding moving parts and the like. About 10 percent of accidents in industry are said to be due to mechanical causes.

Though not alarming it can be reduced or avoided by being careful while operating, e.g. traumatic injuries due to projectiles carelessness while using sharp instruments aeroters etc.

\section{Psychosocial hazards}

The psychosocial hazards arise from the worker's failure to adapt to an alien psychosocial environment. Frustrations, lack of job satisfaction, insecurity, emotional tension are some of the psychosocial factors that undermine the physical and mental health of the workers.

Stress

Stress is the most common psychological condition that occurs in the dental profession. Stress situations form an inherent part of a dentist's everyday work. Many clinical situations are the source of stress to a dentist and these include, among others, procedures connected with anesthetization of patients, overcoming of pain and fear, unexpected emergency situations in which a patient's health or life is in danger, or procedures with uncertain prognosis.

The following factors such as the necessity to keep a proper professional standard, aspiration to achieve technical perfection, causing pain or fear in patients, the necessity to cope with cancelled visits or late arrivals by patients, having to cope with different levels of cooperation with patients are some of the very important sources of stress in everyday dental practice. 


\section{Legal hazards}

In every country there are relevant statutes and regulations which apply to the practice of dentistry.to help assure a safe work environment in dental treatment, the hazard awareness and prevention of legal risks should be made known to all clinical workers of the dental hospital/clinic.

\section{Other risks}

Mild neuropathy among dental professionals has been shown to be associated with high frequency vibrations from dental equipments, particularly high and low speed handpieces and ultrasonic scalers.

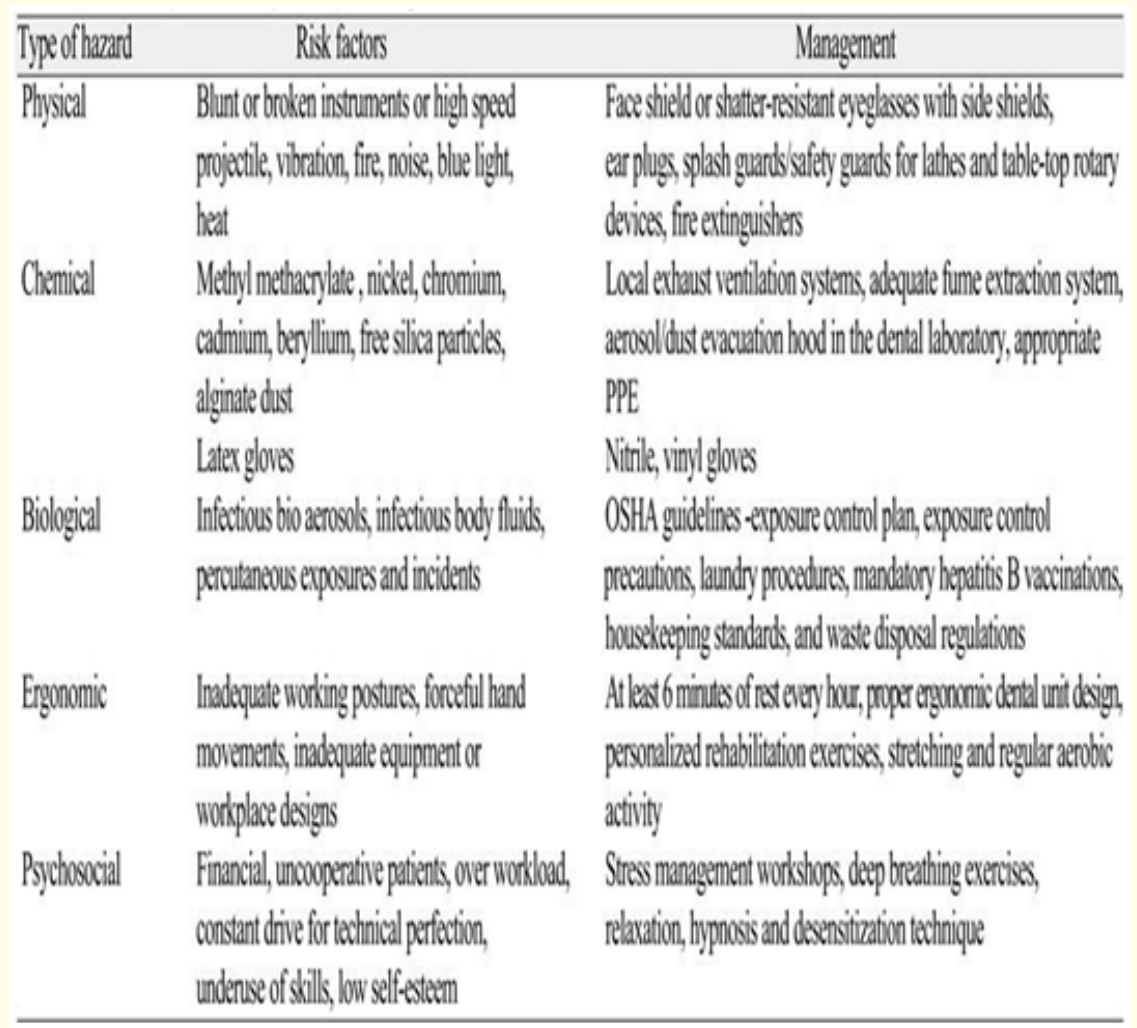

Figure 5: Risk factor and management.

Prevention of occupational hazards

Education is one of the important strategies for the prevention of occupational injuries and diseases. The role of one's occupation as an important factor in maintaining personal health needs to be constantly emphasized so workers understand any possible negative health implication of their jobs and how to minimize them. Concerning prevention, the international literature focuses mostly on infection control and proper handling of potentially infected materials, owing to the high profile of dentistry regarding transmission of infection.

Barrier techniques include gloves, masks, protective eye wear, high power suction and good ventilation to reduce aerosols and vapor dangers. Hypoallergenic nonlatex gloves are proposed to deal with latex allergy. Lead aprons, periodic maintenance of the X-ray machine and radiation level sensors prevent radiation hazards [14]. 


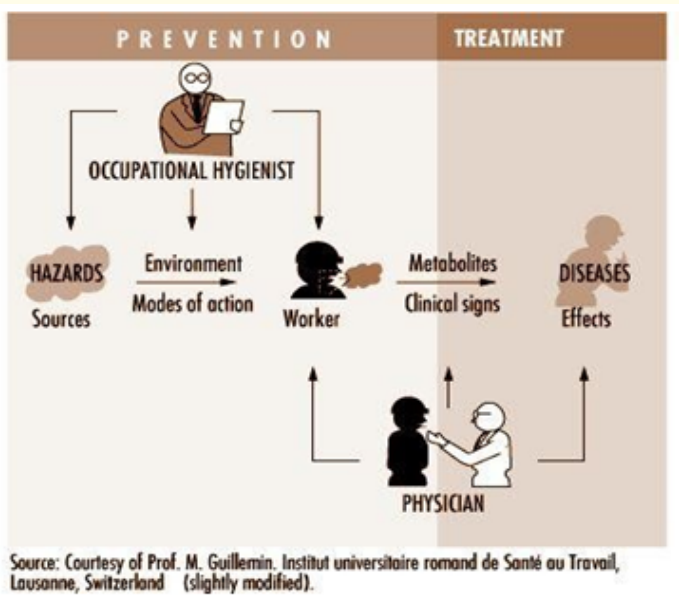

Figure 6
3. Agarwal Neha., et al. "Occupational hazards in modern dentistry". International Journal of Medicine 1.1 (2014): 1-9.

4. Leggat., et al. "Occupational health problems in modern dentistry-a review". Industrial Health 45.5 (2007): 611-621.

\section{Assets from publication with us}

- Prompt Acknowledgement after receiving the article

- Thorough Double blinded peer review

- Rapid Publication

- Issue of Publication Certificate

- High visibility of your Published work

Website: www.actascientific.com/

Submit Article: www.actascientific.com/submission.php

Email us: editor@actascientific.com

Contact us: +919182824667

\section{Conclusion}

Dental health workers are exposed to many occupational hazards ranging from the threat of infectious disease, toxicity to chemicals routinely used in dentistry and musculoskeletal disease consequential to poor working position. A systematic approach to occupational hazards in the dental setting are:

- List all work related tasks and activities,

- Identify potential biological, chemical,

- $\quad$ Physical and psychological hazards associated with each task,

- $\quad$ Assess the risk of the hazards by considering the severity of consequences of exposure, the probability that the exposure will occur and the frequency the task is done,

- Implement the controls for each hazard,

- $\quad$ Evaluate the controls periodically to ensure they are effective.

\section{Bibliography}

1. Soben Peter. $5^{\text {th }}$ edition essentials of public health dentistryOccupational hazards in dentistry.

2. Chopra SS., et al. "Occupational hazards among dental surgeons”. Medical Journal Armed Forces India 63.1 (2007): 23-25. 